\title{
A CROSS-SECTIONAL STUDY OF SUPERIOR THYROID ARTERY IN HUMAN CADAVERS
}

\author{
Veena Vidya Shankar ${ }^{1}$, Komala $N^{* 2}$, Shailaja Shetty ${ }^{3}$. \\ ${ }^{1,{ }^{*} 2}$ MBBS, MD, Associate Professor, Department of Anatomy, Ramaiah Medical College, Banga- \\ lore, Karnataka, India. \\ ${ }^{3}$ MBBS, MD, Professor \& Head, Department of Anatomy, Ramaiah Medical College, Bangalore, \\ Karnataka, India.
}

\section{ABSTRACT}

Introduction: The superior thyroid artery is one of the ventral branches arising from external carotid artery in the neck region but it may also arise from common carotid artery or at bifurcation of common carotid artery. It forms a major source of vascular supply to the thyroid gland along with inferior thyroid artery. The relation of the nerve to the artery and apex of lateral lobe of thyroid gland is extremely variable. Inadvertent ligation of external laryngeal nerve along with superior thyroid artery during thyroidectomy results in paralysis of cricothyroid muscle and produces dysphonia.

Aims: To identify the variations in the site of origin, the level of origin, number and the length of the superior thyroid artery

Materials and Methods: The present study is a cross-sectional study and was carried out in 80 embalmed specimens in Department of Anatomy at Ramaiah Medical College. The superior thyroid artery supplying the thyroid gland was meticulously dissected and digitally photographed. The parameters studied were site of origin, level of origin, number and the length of the artery from the origin to the entry of gland. The measurements were taken three times to avoid intraobserver variation and their mean value has been considered. Data so collected has been entered in a master chart in Microsoft ${ }^{\circledR}$ Excel and has been analyzed using the SPSS version 17.0.

Results: In the present study, superior thyroid artery was single, arising predominantly from external carotid artery at the level of upper border of thyroid cartilage and main trunk measured $4.38 \pm 1.42 \mathrm{~cm}$.

Conclusion: Knowledge of the anatomical variations of superior thyroid artery with respect to its origin, level of origin and its relation to external laryngeal is important before attempting any interventional or surgical procedure in the neck region.

KEY WORDS: Thyroid Gland, External Carotid Artery, Common Carotid Artery, Superior Thyroid Artery, Carotid Bifurcation.

Address for Correspondence: Dr. Komala N, Associate Professor, Department of Anatomy, Ramaiah Medical College, Bangalore - 560054, Karnataka, India. Contact No.: Mobile: 9480259177,

E-Mail: komas2001@yahoo.com

\section{Access this Article online}

\section{Quick Response code}

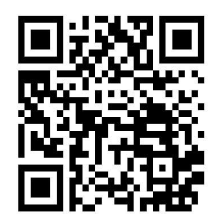

DOI: $10.16965 /$ ijar.2017.463

Web site: International Journal of Anatomy and Research

ISSN 2321-4287

www.ijmhr.org/ijar.htm

Received: 27 Sep 2017

Peer Review: 29 Sep 2017

Revised: None
Accepted: 08 Nov 2017

Published (O): 01 Dec 2017

Published (P): 01 Dec 2017

\section{INTRODUCTION}

The superior thyroid artery is one of the ventral branches arising from external carotid artery in the neck region but it may also arise from common carotid artery or at bifurcation of common carotid artery. It forms a major source of 
vascular supply to the thyroid gland along with inferior thyroid artery. Thyroid gland is the largest endocrine gland and is responsible for the maintenance of basal metabolic rate of the body[1,2].

The high vascularity of thyroid gland is equivalent to that of kidney and suprarenal gland and is $5 \mathrm{ml} / \mathrm{gm} / \mathrm{min}$ under conditions of extreme stimulation[3]. The superior thyroid artery courses towards the apex of lateral lobe of thyroid gland and is accompanied by the external branch of superior laryngeal nerve to which it is closely related. The relation of the nerve to the artery and apex of lateral lobe of thyroid gland is extremely variable. Inadvertent ligation of external laryngeal nerve along with superior thyroid artery during thyroidectomy results in paralysis of cricothyroid muscle and produces dysphonia [3]. The superior thyroid artery divides into anterior and posterior divisions close to the apex. The anterior branches of both superior thyroid arteries anastomoses along the upper border of isthmus thereby establishing a collateral circulation route between the two external carotid arteries in cases of unilateral blockage of common carotid artery [4].

An indepth knowledge of the arterial variations is crucial to get bloodless fields for surgical procedures in the head and neck region like in radical neck dissection, thyroidectomy, carotid endarterectomy, catheterization, aneurysm reconstruction, interventional radiology, selective embolisation of thyroid, head and neck tumours[5]. The superior thyroid artery is frequently used as a recipient vessel for microvascular free tissue transfer in head and neck surgery [6]. The superior thyroid artery perforator flap exhibits reliable vascular anatomy and so is ideal in the reconstruction of a wide range of head and neck defects[7].

AIM: To identify the variations in the number, length, site of origin and the level of origin of superior thyroid artery.

\section{MATERIALS AND METHODS}

The present study is a cross-sectional study and was carried out in forty embalmed cadavers in Department of Anatomy at Ramaiah Medical College. Based on the previous studies conducted by Dr Pushpalatha [8] et al titled 'Study on variations in origin of superior thyroid artery' it was found that percentage of superior thyroid artery arising from ECA was $68 \%$. Considering a relative precision of $15 \%$ and alpha error of $5 \%$, sample size was estimated to be 80 . The superior thyroid artery supplying the thyroid gland was meticulously dissected and digitally photographed. The measurements were taken three times to avoid intraobserver variation and their mean value has been considered. Data so collected has been entered in a master chart in Microsoft ${ }^{\circledR}$ Excel and has been analyzed using the SPSS version 17.0.

Parameters studied:

1. Site of origin of superior thyroid artery from external carotid artery, from bifurcation of common carotid artery or from common carotid artery

2. The level of origin of superior thyroid artery in relation to the upper border of thyroid cartilage - at the level or below the level or above the level of upper border of thyroid cartilage.

3. Number of superior thyroid artery whether it is single or double.

4. The length of main trunk of superior thyroid artery in centimeters was measured from its origin to the apex of lateral lobe of the thyroid gland.

5.Statistical Methods: Descriptive statistics such as mean and standard deviation has been computed for different parameters. $P$ value $<0.05$ has been considered as statistically significant. Data analysis was carried out using SPSS version 18.0.chicago SPSS Inc.

\section{RESULTS}

Table 1: Site of origin of superior thyroid artery in cadavers.

\begin{tabular}{|c|c|c|c|c|}
\hline \multirow{2}{*}{ Side } & \multirow{2}{*}{$\mathrm{n}=80$} & \multicolumn{3}{|c|}{ Site of origin of superior thyroid artery } \\
\cline { 3 - 5 } & & $\begin{array}{c}\text { From External } \\
\text { carotid artery }\end{array}$ & $\begin{array}{c}\text { From Bifurcation of } \\
\text { Common carotid artery }\end{array}$ & $\begin{array}{c}\text { From Common } \\
\text { carotid artery }\end{array}$ \\
\hline Right & 40 & $25(62.5 \%)$ & $5(12.5 \%)$ & $10(25 \%)$ \\
\hline Left & 40 & $18(45 \%)$ & $7(17.5 \%)$ & $15(37.5 \%)$ \\
\hline Total & $80(100 \%)$ & $43(53.75 \%)$ & $12(15 \%)$ & $25(31.265 \%)$ \\
\hline
\end{tabular}

In the present study of 80 superior thyroid arteries with 40 right and 40 left arteries, it was observed that in $43(53.75 \%)$ it was arising from external carotid artery, in 12(15\%) from bifurca- 
tion of common carotid artery and in $25(31.265 \%)$ from common carotid artery. On both right and left side, the first common site of origin is from external carotid artery, second common site is from common carotid artery and third common site is from the bifurcation of common carotid artery.

The superior thyroid artery was arising at the level of upper border of thyroid cartilage in 13(16.25\%); below the level in 8(10\%) and above the level in 59(73.75\%). On both right and left sides it was predominantly arising above the level followed by at the level and below the level of upper border of thyroid cartilage.

Table 2: Level of origin of superior thyroid artery.

\begin{tabular}{|c|c|c|c|c|}
\hline \multirow{2}{*}{ Side } & \multirow{2}{*}{$\mathrm{n}=80$} & \multicolumn{3}{|c|}{ Level of origin in relation to upper border of thyroid } \\
& & cartilage \\
\cline { 3 - 5 } & & At the level & Below the level & Above the level \\
\hline Right & 40 & $6(15 \%)$ & $2(5 \%)$ & $32(80 \%)$ \\
\hline Left & 40 & $7(17.5 \%)$ & $6(15 \%)$ & $27(67.5 \%)$ \\
\hline Total & $80(100 \%)$ & $13(16.25 \%)$ & $8(10 \%)$ & $59(73.75 \%)$ \\
\hline
\end{tabular}

Table 3: Number of superior thyroid artery.

\begin{tabular}{|c|c|c|c|}
\hline Side & $\mathbf{n}$ & $\begin{array}{c}\text { Number of superior thyroid } \\
\text { artery }\end{array}$ \\
\hline & 80 & Single & Double \\
\hline Right & 40 & $39(73.75 \%)$ & $1(2.5 \%)$ \\
\hline Left & 40 & $40(100 \%)$ & 0 \\
\hline Total & $100 \%$ & $79(98.75 \%)$ & $1(1.25 \%)$ \\
\hline
\end{tabular}

Table 4: Length of main trunk of superior thyroid artery.

\begin{tabular}{|c|c|c|c|}
\hline Side & $n=80$ & $\begin{array}{c}\text { Mean Length of main trunk of } \\
\text { superior thyroid artery in } \\
\text { centimetres }\end{array}$ & $\begin{array}{c}\text { Overall mean length of main } \\
\text { trunk of superior thyroid artery } \\
\text { in centimetres }\end{array}$ \\
\hline Right & 40 & $4.48 \pm 1.53$ & \multirow{2}{*}{$4.38 \pm 1.42$} \\
\hline Left & 39 & $4.28 \pm 1.30$ & \\
\hline
\end{tabular}

Fig. 1: Origin of Superior thyroid artery (STA) from External carotid artery (ECA).

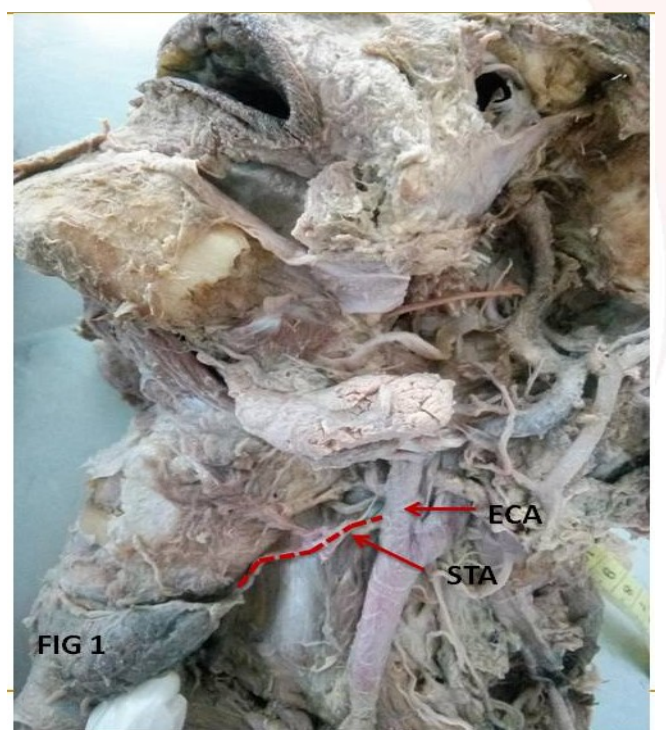

In 79 specimens, the superior thyroid artery was single and only one specimen on the right side had double superior thyroid artery arising from external carotid artery as single trunk bifurcating at its origin.

The overall mean length of the superior thyroid artery was found to be $4.38 \pm 1.42 \mathrm{~cm}$ with right being $4.48 \pm 1.53 \mathrm{~cm}$ and left being $4.28 \pm 1.30 \mathrm{~cm}$. Fig. 2: Origin of Superior thyroid artery (STA) from Common carotid artery (CCA).

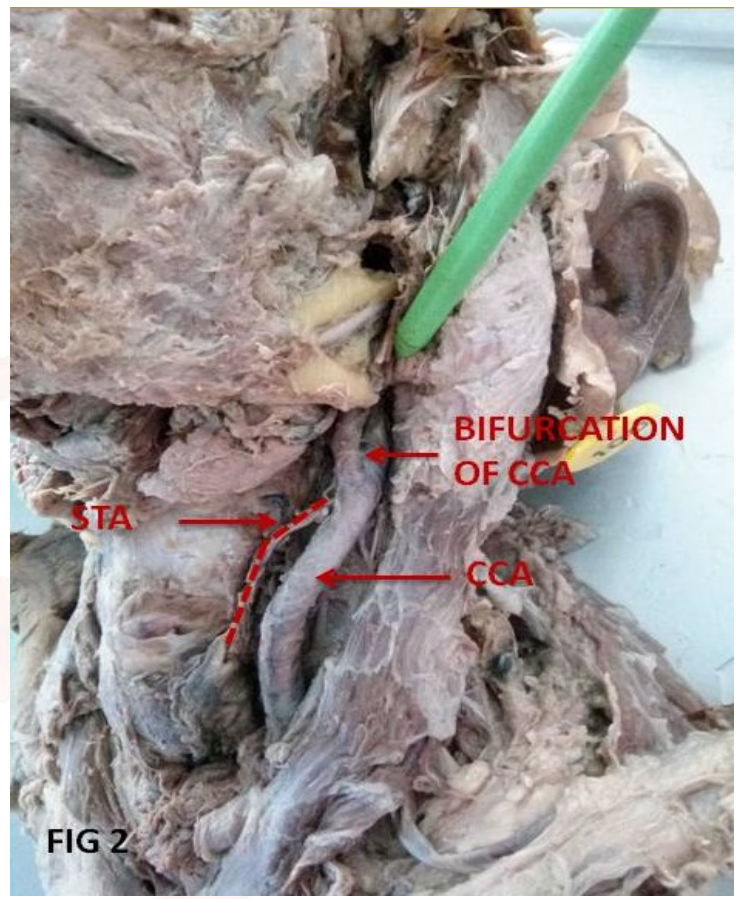

Fig. 3: Origin of Superior thyroid artery (STA) from bifurcation of Common carotid artery (CCA).

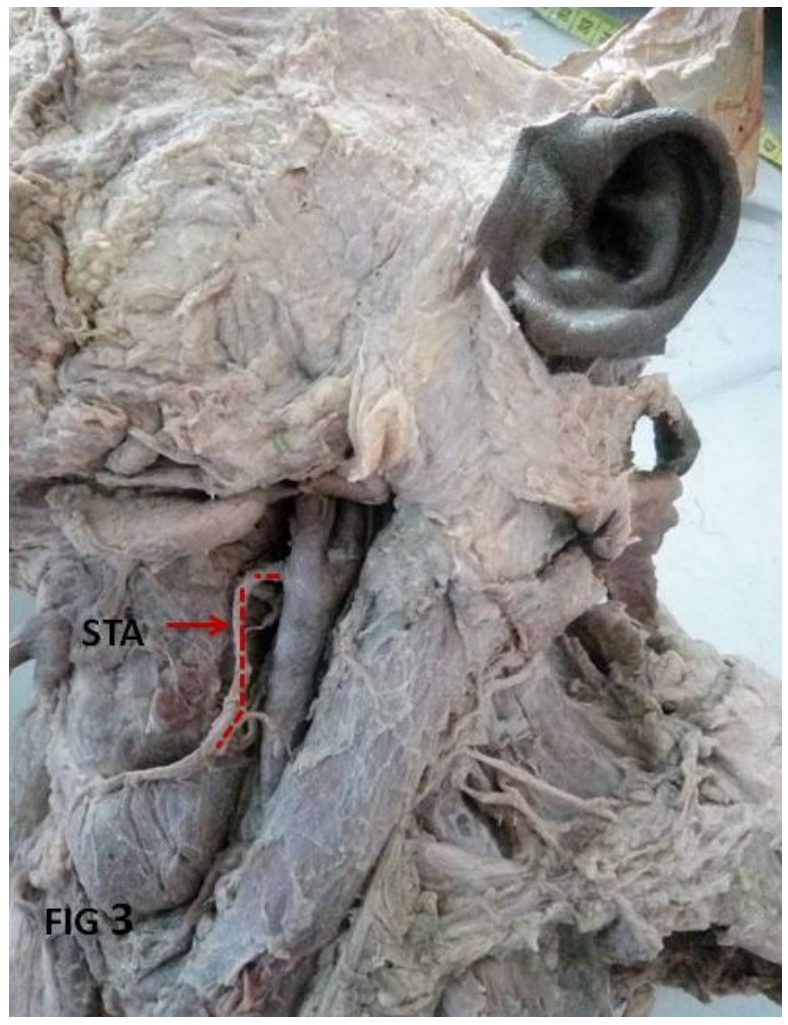




\section{DISCUSSION}

Table 5: Comparison of

\begin{tabular}{|l|c|c|c|}
\hline \multirow{2}{*}{ Authors } & \multicolumn{3}{c|}{ Origin of superior thyroid artery } \\
\cline { 2 - 4 } & $\begin{array}{c}\text { External carotid } \\
\text { artery }\end{array}$ & $\begin{array}{c}\text { Bifurcation of } \\
\text { common carotid } \\
\text { artery }\end{array}$ & $\begin{array}{c}\text { Common } \\
\text { carotid artery }\end{array}$ \\
\hline Adachi B (1928) [9] & 61 & 27 & 13 \\
\hline Aaron and Chawaf (1967) [10] & 49 & 44 & 13 \\
\hline Poissel and Golth (1974) [11] & 70 & 24 & 6 \\
\hline Banna and Lasjaunias (1990) [12] & 68 & 22 & 10 \\
\hline Lucev et al. (2000) [13] & 30 & 22.5 & 47.5 \\
\hline Zümre et al. (2005) [14] & 25 & 70 & 5 \\
\hline Lo et al. (2006) [15] & 46.2 & 1.5 & 52.3 \\
\hline Ozgur et al. (2008) [16] & 25 & 40 & 35 \\
\hline Kanta roy et al (2009) [17] & 78.94 & 13.15 & 7.89 \\
\hline Teresa Va'zquez et al (2009) [18] & 23 & 49 & 26.6 \\
\hline Harrigan and Deveikis (2009) [19] & 46 & 2 & 52 \\
\hline Sanjeev et al. (2010) [20] & 64.86 & 0 & 35.14 \\
\hline Takkallapalli Anitha et al (2011) [21] & $59 \%$ & $19 \%$ & $21 \%$ \\
\hline João R. Mata et al (2012) [22] & 51.2 & 45.3 & 3.5 \\
\hline Abhijeet Joshi et al (2014) [23] & 66.67 & 31.81 & 1.51 \\
\hline Rajamadhava .R et al (2015) [24] & 100 & 0 & 0 \\
\hline Pushpalatha [8]et al (2015) [8] & 68 & 8 & 24 \\
\hline Shivaleela et al (2016) [25] & 76.19 & 21.43 & 2.38 \\
\hline Vijaylakshmi et al (2017) [3] & 48.33 & 35 & 15 \\
\hline Present study & $\mathbf{5 3 . 7 5 \%}$ & $\mathbf{1 5}$ & $\mathbf{3 1 . 2 5}$ \\
\hline Surperior thy roid arterr & & & \\
\hline
\end{tabular}

In the present study, superior thyroid artery origin from external carotid artery was observed in $53.75 \%$ which is similar to that reported in various studies $[3,8-11,12,20-25]$ in the range of $30 \%$ to $100 \%$. This is most common origin of superior thyroid artery.

The superior thyroid artery origin from common carotid artery in the present study is $31.25 \%$ and similar in other studies $[15,16,18,20,21]$ in a range of $1.51 \%$ to $52.3 \%$. This is the second common position in present study. The superior thyroid artery origin from bifurcation of common carotid in the present study is $15 \%$ and similar in other studies $[8,13,15,19,21]$ in a range of $1.5 \%$ to $49 \%$. This is the third common position in present study.

Table 6: Comparison of level of origin of superior thyroid artery in percentages in various studies.

\begin{tabular}{|c|c|c|c|}
\hline \multirow{2}{*}{ Authors } & \multicolumn{3}{|c|}{$\begin{array}{c}\text { Level of origin in relation to upper } \\
\text { border of thyroid cartilage }\end{array}$} \\
\cline { 2 - 4 } & $\begin{array}{c}\text { At the } \\
\text { level }\end{array}$ & $\begin{array}{c}\text { Below the } \\
\text { level }\end{array}$ & $\begin{array}{c}\text { Above the } \\
\text { level }\end{array}$ \\
\hline Kanta roy et al (2009) [17] & 24.56 & 57.02 & 18.42 \\
\hline João R. Mata et al (2012) [22] & 45.3 & 3.5 & 51.2 \\
\hline Abhijeet Joshi et al (2014) [23] & 13.64 & 0 & 86.36 \\
\hline Pushpalatha et al (2015) [8] & $36 \%$ & 6 & 48 \\
\hline Shivaleela et al (2016) [25] & 11.9 & 0 & 88.09 \\
\hline Present study & $\mathbf{1 6 . 2 5}$ & $\mathbf{1 0}$ & $\mathbf{7 3 . 7 5}$ \\
\hline
\end{tabular}

The superior thyroid artery origin was predominantly above the level of upper border of thyroid cartilage in present study $(73.75 \%)$ and in various studies $[8,22,23,25]$ who have reported in a range of $18.42 \%$ to $88.09 \%$ except in one study (18.42\%) where it was least common level of origin. The second common level of origin in the present study is at the level of upper border of thyroid cartilage $(16.25 \%)$ and in other studies $[8,22,23,25]$ was found in a range of $11.90 \%$ to $36 \%$. The third common level of superior thyroid artery origin was below the level of upper border of thyroid cartilage in present and two other studies $[8,22]$ and in one study[17] it was the most common level. In two other studies $[23,25]$ superior thyroid artery origin below the level of upper border of thyroid cartilage was absent.

Table 7: Comparison of Mean Length of main trunk of superior thyroid artery on both sides in various studies.

\begin{tabular}{|c|c|c|}
\hline \multirow{2}{*}{ Authors } & \multicolumn{2}{|c|}{$\begin{array}{c}\text { Mean Length of main trunk of } \\
\text { superior thyroid artery }\end{array}$} \\
\cline { 2 - 3 } & Right & Left \\
\hline Kanta roy et al (2009) [17] & $2.56 \pm 0.71 \mathrm{~mm}$ & $2.63 \pm 0.72$ \\
\hline Vijaylakshmi et al (2017) [3] & 3.56 & 3.66 \\
\hline Present study & $\mathbf{4 . 4 8 \pm 1 . 5 3}$ & $\mathbf{4 . 2 8} \pm 1.30$ \\
\hline
\end{tabular}

The overall mean length of the superior thyroid artery was found to be $4.38 \pm 1.42 \mathrm{~cm}$ with right 
being $4.48 \pm 1.53 \mathrm{~cm}$ and left being $4.28 \pm 1.30 \mathrm{~cm}$ which is higher than that have been reported in two other studies $[3,17]$.

\section{CONCLUSION}

In the present study, superior thyroid artery was single, arising predominantly from external carotid artery at the level of upper border of thyroid cartilage and main trunk measured $4.38 \pm 1.42 \mathrm{~cm}$. Knowledge of the anatomical variations of superior thyroid artery with respect to its origin, level of origin and its relation to external laryngeal is important before attempting any interventional or surgical procedure in the neck region.

\section{ACKNOWLEDGEMENTS}

We would like to thank $\mathrm{Dr}$ Kalpana $\mathrm{R}$ for the timely help during the study.

\section{Conflicts of Interests: None}

\section{REFERENCES}

[1]. Standring S. Gray's Anatomy 39 ed, Elsevier Churchill Livingstone, Edinburgh, London, New York, Philadelphia, Sydney, Toronto 2005;749-754.

[2]. Datta, AK. Essentials of human anatomy. 2nd Ed. Calcutta, Current Books International 1994; 127-132.

[3]. Vijay Laxmi, Kulbir Kaur, Palak Chhabra. Superior Thyroid Artery: its Origin, Length, Relations and Branches. International Annals of Medicine. 2017;1(4).

[4]. Macchi C, Catini C. The anatomy and clinical importance of the collateral circle between the external carotid arteries through an anastomosis between the superior thyroid arteries. Ital J Anat Embryol 1993;98:197-205.

[5]. Yogesh S Ganorkar, Madhavi Ramteke, Ashish Radke. Anatomical Variation of Left Superior Thyroid Artery: A Case Report. IOSR Journal of Dental and Medical Sciences (IOSR-JDMS). 2016; 15 (2): 69-70.

[6]. Gursharan Singh Dhindsa1, Shubhpreet Sodhi .Variation in the Origin of Superior Thyroid Artery. Journal of Evolution of Medical and Dental Sciences. 2014;3( 22): 5969-5972.

[7]. Jeremy L. Wilson, Warren M. Rozen, Richard Ross, Michael W. Findlay, Mark W. Ashton, Felix C. Behan. Plastic and Reconstructive Surgery. 2012;129(3): 641 646.

[8]. Pushpalatha M, Vidhya K. S. Study on variations in origin of superior thyroid artery. J Evid Based Med Healthc. 2015; 2(59):8968 - 8970.

[9]. Adachi B. Das arteriensystem der japaner. Kyoto: Maruzen Co; 1928. pp 54-82.

[10]. Aaron C, Chawaf AR. Variations de la carotide externeet de ses branches. Bull Assoc Anat.1967 13:125-134.
[11]. Poisel S, Golth D. Variability of the large arteries in the carotid triangle. Wien Med Wochenschr. 1974;15:229-232.

[12]. Banna M, Lasjaunias P. The arteries of the lingual thyroid: angiographic findings and anatomic variations. Am J Neuro-radiol. 1990;11:730-732.

[13]. Lucev N, Babinac D, Maric I, Drescik I, Variations of the great arteries in the carotid triangle. Otolaryngol Head and Neck Surgery. 2000;122:590- 591.

[14]. Zümre O., Salbacak A., Ciçekcibaoi A.E., Tuncer I., Seker $M$. Investigation of the bifurcation level of the common carotid artery and variations of the branches of the external carotid artery in human fetuses. Ann. Anat. 2005; 187: 361-369.

[15]. Lo A., Oehley M., Bartlett A., Adams D., Blyth P., Al-Ali S. Anatomical variations of the common carotid artery bifurcation. ANZ J. Surg. 2006; 76: 970-972.

[16]. Ozgur Z., Govsa F., Ozgur T. Assessment of origin characteristics the front branches of the external carotid artery. J. Craniofac. Surg. 2008; 19: 1159-1166.

[17]. Kanta Roy Rimi, Shamim Ara, Motahar Hossain, KM Shefyetullah, Humaira Naushaba, BK Bose. Postmortem Study of Thyroid Arteries in Bangladeshi People. Bangladesh Journal of Anatomy. 2009; 7(1):26-33.

[18]. Vazquez T, Cobiella R, Maranillo E, Valderrama FJ, $\mathrm{McHanwell} \mathrm{S}$. Anatomic variations of the superior thyroid and superior laryngeal arteries. Head Neck; 2009; 31; 1078-1085.

[19]. Harrigan MR, Deveikis JP. Handbook of Cerebrovascular Disease and Neurointerventional Technique. Humana Press, New York. 2009:11.

[20]. Sanjeev IK, Anita H, Ashwini M, Mahesh U, Rairam GB. Branching pattern of external carotid artery in human cadavers. J. Clin. Diagn. Res. 2010; 4: 31283133.

[21].Takkallapalli Anitha, Dattatray Dombe, Krishnamurthy Asha, Sanjay Kalbande, Clinically relevant variations of the superior thyroid artery: An anatomic guide for neck surgeries, Int J Pharm Biomed Sci 2011;2(2):51-54.

[22]. João R. Mata, Fabiana R. Mata, Márcio C. R. Souza, Hisao Nishijo, Tales A. Aversi Ferreira. Arrangement and prevalence of branches in the external carotid artery in humans. Italian Journal of Anatomy and Embryology. , 2012; 117(2): 65-74.

[23]. Abhijeet Joshi, Sumit Gupta, V H Vaniya Anatomical variation in the origin of superior thyroid artery and it's relation with external laryngeal nerve. National journal of medical research. 2014;4(2):138- 41.

[24]. Rajamadhava R, Kafeel Hussain A, Swayam Jothi S, Hemanth Kommuru, Sujatha N. Variations In The Course Of the Superior and Inferior Thyroid Arteries In Relation To the External \& Recurrent Laryngeal Nerves. IOSR Journal of Dental and Medical Sciences (IOSR-JDMS). 2015; 14(6): 05-09.

[25]. Shivaleela C, Anupama. D, Lakshmi prabhasubhash $R$. Study of anatomical variations in the origin of superior thyroid artery. International journal of anatomy and research.2016;4(1):1765-68. 